\title{
A Comparative Study on Consumption Functions: The Case of the European Union*
}

\author{
Mustafa BILIK' ${ }^{1}$ \\ Recep KÖK²
}

\begin{abstract}
The consumption function describes the relationship between consumption expenditures and income. As is well known, the distribution of macroeconomic data such as income and consumption is unequal. Accordingly, estimators derived from linear models may be inefficient. This study attempted to reach efficient estimators, using gamma distribution, within the limits of this study. The main purpose of this study is to estimate parameters of mainstream consumption functions using the panel-data of EU members and negotiating countries. Using data from the World Bank, the European Union Macroeconomic Database (AMECO), and the Bank of International Settlement (BIS), consumption functions were estimated by the Generalized Linear Model (GLM) approach. The reliability of the estimators was tested with the Generalized Moments Method (GMM). Furthermore, the study uses GLM, based on machine learning, to obtain robust estimators for overfitting. Findings of all three methods are compatible with each other and the "Permanent Income" hypothesis verified.
\end{abstract}

Keywords: Consumption Function, Marginal Propensity to Consume, Absolute Income Hypothesis, Life-cycle Hypothesis, Permanent Income Hypothesis.

JEL Codes: $\mathrm{C} 12, \mathrm{C} 22, \mathrm{D} 12, \mathrm{E} 21$.

\section{INTRODUCTION}

In many developed and developing economies, household consumption expenditures constitute the largest part of Gross Domestic Product. According to Keynes (1936), consumption is the sole purpose and objective of all economic activity. The main source of this doctrine is that current consumption expenditures are the most crucial component of aggregate demand and that the planned consumption expenditures are the main driving force of the other components.

Keynes divided the factors determining the consumption propensity into objective and subjective elements. The objective factors are prices, taxes, wealth, interest rates, income distribution and changes in the relationship between current income and income expectations (Keynes, 1936). These are the foundations of mainstream consumption theories (Pressman, 1997).
For example, the phenomenon of wealth is the main source of Modigliani's (1963) 'life cycle' hypothesis, and interest rates and income expectations are the main sources of Friedman's (1957) "permanent income hypothesis". Unlike the Keynesian view, the principal determinant of consumption is not current income but the permanent or life-cycle income. Accordingly, consumers spend a certain share of their lifetime or permanent income. Even if there is a change in current income, this spreads over periods and the concept of "consumption smoothing" arises. Even in developed countries, while a certain share of the decision making units makes consumption decisions based on the current income, another determines consumption decisions based on the permanent income. These findings suggest that some economic decision-making units behave in compliance with the Keynesian approach in the short-run, while in the long run certain share of

\footnotetext{
"This study is based on the first chapter of the PhD disseration under the title "Analyzing the Relationship Between Income Distribution and Household Expenditures over Comperative Consumption Functions: The Case of the European Union"

1 mustafa.bilik@deu.edu.tr

${ }^{2}$ recep.kok@deu.edu.tr
} 
the consumption expenditures are explained by the permanent income hypothesis.

This study presents information on the theoretical basis of consumer behavior in the EU member states and the cluster of countries in the negotiation process. This process requires the estimation of consumption trends in the short and long term. At the same time, the study tests the liquidity constraints of consumers and the excess sensitivity of consumption expenditures to income (Flavin, 1981; Dornbusch, Fischer \& Bossons, 1987 ) in the framework of the consumption function literature.

The global income and consumption inequality require that the average, standard deviation, skewness, and kurtosis criteria (moments) of the series should be taken into consideration in the estimation process. The Generalized Method of Moments (GMM) allows estimators based on these characteristics. Within this framework, GLM estimators was tested with the GMM method. This approach is to determine whether the coefficients are reliable. Finally, machine learning-based GLM findings are also included as the parameters of the permanent income hypothesis estimated under the assumption of adaptive expectations and are questionable in terms of predictive potential.

\section{EMPIRICAL LITERATURE ON CONSUMPTION FUNCTIONS}

There is inconsistency in the origin of the empirical studies on consumption between Keynesian consumption theory and the empirical findings of Kuznets (1946). In this section, applied studies concerning consumption theories are presented in Table 1 to Table 3. In macroeconomics, the consumption function literature was developed over linear models before the "spurious regression" phenomenon and the development of "unit root" and "co-integration" approaches. Therefore, the regression models established between the disposable income and consumption expenditures in these studies are controversial.

The limited extent of applied literature on the absolute income hypothesis are presented in Table 1. In addition to these studies, Kaldor (1955) analyzes household income into two parts as labour and profit income, within the framework of the Keynesian consumption function. The findings in the study support that mpc out of wage is lower than the mpc out of profit.

Table 2 presents the applied literature on the life cycle and permanent income hypotheses. The most important constraint on the empirical Life Cycle Hypothesis is the question of whether current data supports the fundamental hypothesis (Deaton, 2005).

The Life Cycle Hypothesis presumes that savings made in the working period will finance the retirement period. Therefore, "consumption smoothing" occurs in the life cycle. However, studies on the US and UK revealed that consumption expenditures fall relatively low during retirement (Banks et al., 1988; Hurd \& Rohwedder, 2005). Additionally, the absence of a bequest motive-one of the fundamental assumptions of the Life Cycle hypothesis- also did not correspond with actual observations. In the basic sense, the fall in consumption expenditures during the retirement period is called the "retirement puzzle"(Kankaanranta, 2006). Smith (2004) presents findings that consumption of durable goods decreased during retirement, but the consumption of non-durables remained the same.

Table 1: Empirical Literature on the Absolute Income Hypothesis

\begin{tabular}{|c|c|c|c|}
\hline Authors & Sample & Method & Findings \\
\hline Davis (1959) & USA (1929-1940) & $\begin{array}{l}\text { Linear Regression } \\
\text { (OLS) }\end{array}$ & $\begin{array}{l}\text { The consumption function is consistent with the } \\
\text { Keynesian absolute income hypothesis. }\end{array}$ \\
\hline Ferber (1966) & $\begin{array}{c}\text { USA (1929-1940), } \\
(1947-1957),(1958-1968)\end{array}$ & $\begin{array}{l}\text { Linear Regression } \\
\text { (OLS) }\end{array}$ & $\begin{array}{l}\text { The absolute income hypothesis is valid. MPCs vary } \\
\text { between periods. }\end{array}$ \\
\hline Okçu (2008) & Turkey (1987-2007) & $\begin{array}{l}\text { Cointegration } \\
\text { Analysis }\end{array}$ & $\begin{array}{l}\text { The absolute income hypothesis rejected. } \mathrm{Mpc}=0.89 \\
\mathrm{apc}=0.69, \text { but no long-term cointegration was observed. }\end{array}$ \\
\hline $\begin{array}{l}\text { Carruth, Gibson, \& } \\
\text { Tsakalotos, (2010) }\end{array}$ & EU & OLS & $\begin{array}{l}\text { Consumption functions are differentiating between } \\
\text { countries. }\end{array}$ \\
\hline Alimi, (2013) & Nigeria (1970-2011) & $\begin{array}{l}\text { Time Series } \\
\text { Analysis }\end{array}$ & $\begin{array}{l}\text { For the short run, the absolute income hypothesis } \\
\text { confirmed. }(\mathrm{mpc}=0.49-0.79)\end{array}$ \\
\hline Aras (2014) & Turkey (1998-2010) & $\begin{array}{l}\text { Linear Regression } \\
\text { (OLS) }\end{array}$ & $\begin{array}{l}\text { The absolute income hypothesis is accepted, and } \\
\text { the emphasis placed on the phenomenon of lagging } \\
\text { consumption. }(\mathrm{Mpc}=0.66 .)\end{array}$ \\
\hline lanole \& Elena, (2015) & EU (2000-2013) & Panel data analysis & The absolute income hypothesis validated. $(\mathrm{mpc}=0.58)$ \\
\hline
\end{tabular}

Source: Prepared by authors. 
Table 2: Empirical Literature on Life Cycle and Permanent Income Hypothesis

\begin{tabular}{|c|c|c|c|}
\hline Authors & Sample & Method & Findings \\
\hline Slacalek (2004) & $\begin{array}{l}\text { OECD Countries } \\
(1960-2000)\end{array}$ & $\begin{array}{l}\text { Cointegration } \\
\text { Approach }\end{array}$ & $\begin{array}{l}\text { There is long-term relation between income, } \\
\text { wealth and consumption. }\end{array}$ \\
\hline Slacalek (2009) & $\begin{array}{l}\text { OECD Countries } \\
(1960-2000)\end{array}$ & IV Approach & $\begin{array}{l}\text { There is a wealth effect on consumption } \\
\text { expenditures. }\end{array}$ \\
\hline Hayashi (1982) & USA (1948-1978) & $\begin{array}{l}\text { OLS and Tobit } \\
\text { Regression }\end{array}$ & $\begin{array}{l}\text { The permanent income hypothesis accepted } \\
\text { for the durable goods but rejected for the non- } \\
\text { durable goods. }\end{array}$ \\
\hline Souleles (2002) & USA (1980-1991) & OLS & MPC is approximately 0.7 on tax returns. \\
\hline Manitsaris (2006) & Euro Area (1980-2005) & Panel Data Analysis & $\begin{array}{l}\text { The permanent income hypothesis is accepted. } \\
\text { (MPC estimated between } 0.7-0.85 \text { ). }\end{array}$ \\
\hline $\begin{array}{l}\text { DeJuan, Seater, \& } \\
\text { Wirjanto (2006) }\end{array}$ & $\begin{array}{l}\text { West Germany } \\
(1980-1986)\end{array}$ & $\begin{array}{l}\text { Time Series } \\
\text { Analysis }\end{array}$ & $\begin{array}{l}\text { The permanent income hypothesis is not } \\
\text { accepted. }\end{array}$ \\
\hline $\begin{array}{l}\text { Jawadi \& Sousa, } \\
\text { (2015) }\end{array}$ & $\begin{array}{l}\text { USA, UK and EURO } \\
\text { Area } \\
\text { (1947 Q1-2008 Q4) }\end{array}$ & $\begin{array}{l}\text { Quantile } \\
\text { Regression, Linear } \\
\text { Models }\end{array}$ & Mpc was estimated to be approximately 0.7. \\
\hline Alimi (2015) & $\begin{array}{l}\text { Nigeria and South } \\
\text { Africa }\end{array}$ & $\begin{array}{l}\text { Time Series } \\
\text { Analysis }\end{array}$ & $\begin{array}{l}\text { In both countries, the permanent income } \\
\text { hypothesis accepted. }\end{array}$ \\
\hline $\begin{array}{l}\text { Bilgili \&Bağlıtaş, } \\
\text { (2016) }\end{array}$ & Turkey (1998-2012) & $\begin{array}{l}\text { Time Series } \\
\text { Analysis }\end{array}$ & $\begin{array}{l}\text { The absolute income hypothesis is accepted for } \\
\text { Turkey }(\mathrm{mpc}=0.7-0.8) .\end{array}$ \\
\hline $\begin{array}{l}\text { Altunç \& Aydın, } \\
\text { (2014) }\end{array}$ & $\begin{array}{l}\text { D-8 Countries } \\
(1980-2010)\end{array}$ & $\begin{array}{l}\text { Cointegration } \\
\text { Approach }\end{array}$ & $\begin{array}{l}\text { Permanent Income Hypothesis accepted for D-8 } \\
\text { countries. }\end{array}$ \\
\hline $\begin{array}{l}\text { Carroll,Slacalek,\& } \\
\text { Tokuoka, (2014) }\end{array}$ & $\begin{array}{l}15 \text { Europe Country } \\
\text { (2013) }\end{array}$ & $\begin{array}{l}\text { Calibration } \\
\text { Techniques }\end{array}$ & $\begin{array}{l}\text { Wealth and wealth inequality effect both } \mathrm{mpc} \\
\text { and the distribution of } \mathrm{mpc} \text { among households. } \\
\text { MPC estimated between } 0.2 \text { and } 0.6 \text {. }\end{array}$ \\
\hline
\end{tabular}

Source: Prepared by the authors.

Table 3: Empirical Literature on the Random Walk Hypothesis

\begin{tabular}{|c|c|c|c|}
\hline Authors & Sample & Method & Findings \\
\hline Flavin, (1981) & USA (1949-1979) & $\begin{array}{l}\text { Maximum Likelihood } \\
\text { Approach }\end{array}$ & $\begin{array}{l}\text { Consumption expenditures are sensitive to } \\
\text { current income. In the short run the } \mathrm{mpc} \text { was } \\
\text { estimated at }=0.35 \text {. }\end{array}$ \\
\hline $\begin{array}{l}\text { Hall \& Mishkin, } \\
\text { (1982) }\end{array}$ & USA (1969-1975) & $\begin{array}{l}\text { Maximum Likelihood } \\
\text { Approach }\end{array}$ & $\begin{array}{l}\text { Total consumption expenditure }(80 \%) \text { largely } \\
\text { corresponds to the random walk hypothesis. ( } \Lambda \\
=0.8)\end{array}$ \\
\hline $\begin{array}{l}\text { Campbell \& } \\
\text { Mankiw, } \\
\text { (1991) }\end{array}$ & USA (1948-1985) & $\begin{array}{l}\text { Instrumental Variable } \\
\text { Approach }\end{array}$ & $\begin{array}{l}\text { Approximately } 45 \% \text { of consumers determine their } \\
\text { spending decisions according to current income } \\
\text { changes. }(\Lambda=0.8)\end{array}$ \\
\hline Souleles, (2002) & USA (1982) & OLS & $\begin{array}{l}\text { The random walk hypothesis rejected. Liquidity } \\
\text { constraints have an impact. The } \mathrm{mpc} \text { is between } \\
0.6 \text { and } 0.9 \text {. }\end{array}$ \\
\hline Rao, (2005) & $\begin{array}{l}\text { Australia and Fiji } \\
(1970-2005)\end{array}$ & $\begin{array}{l}\text { Instrumental Variable } \\
\text { Approach }\end{array}$ & $\begin{array}{l}\text { The ratio of Keynesian consumers in Australia is } \\
0.3 \text {, while in Fiji it is } 0.52 \text {.) }\end{array}$ \\
\hline Bilgili, (2006) & Turkey (1987-2003) & VAR Approach & The random walk hypothesis rejected. \\
\hline $\begin{array}{l}\text { Alegre \& Pou, } \\
(2008)\end{array}$ & Spain (1986-1996) & GMM & $\begin{array}{l}\text { The behaviour of full-time employed consumers } \\
\text { conforms to the random walk hypothesis. }\end{array}$ \\
\hline $\begin{array}{l}\text { Sivri \& Eryüzlü, } \\
\text { (2010) }\end{array}$ & Turkey (1987-2007) & $\begin{array}{l}\text { Cointegration } \\
\text { Approach }\end{array}$ & $\begin{array}{l}\text { In the sample of Turkey, the random walk } \\
\text { hypothesis rejected. }\end{array}$ \\
\hline Poterba, (2017) & USA (1959-1987) & OLS & $\begin{array}{l}\text { The random walk hypothesis rejected. Mpc ranges } \\
\text { between } 0.12-0.24 \text { out of tax returns. }\end{array}$ \\
\hline
\end{tabular}

Source: Prepared by the authors. 
Table 3 reveals the main empirical studies of the random walk hypothesis. In the applied literature, "excess smoothing" and "excess sensitivity" concepts arise when the hypothesis is the subject of the test. These linked to whether the disposable income series is stationary. In addition to these studies, Deaton (1987) tests the random walk hypothesis with a distinct approach. Here, the variances of the dependent $(\Delta C)$ and the independent variables $(\epsilon)$ were compared. Accordingly, the variance of the error term is greater than the variance of the independent variable. These results show an important finding that the hypothesis is not confirmed. Findings of the empirical literature on the random walk hypothesis revealed that the excess sensitivity hypothesis is verified. Liquidity constraints and the myopia of consumers were presented as the possible cause of this outcome.

The applied literature on the consumption functions was presented in this section. In our study, based on the skewness of the income and consumption distribution, GLM based estimators were obtained and tested with techniques based on GMM and machine learning. In this framework, we presented our contribution to the applied literature.

\section{DATASET AND THE METHOD}

The data set and econometric methods used in estimating consumption functions in the European Union sample presented are in this part of the study. Here, the functions of mainstream consumption theories are comparatively analyzed in the applied perspective.

\subsection{Definition and Source of the Data}

In this study, data from thirty-three countries covering the period of 2000-2017 were employed. The definition and source of the variables are summarized in the table below.

The descriptive statistics of the variables are summarized in Table 5. Accordingly, Luxembourg possesses the highest per capita income ( 112 thousand USD) and Kosovo the lowest (1919 USD). Again, as expected, Luxembourg has the highest per capita expenditure and Kosovo the lowest. The real interest rate fluctuates between $-12 \%$ and $25 \%$ in the period. The house price index (instrument for wealth) varied between 38 and 209 and the average of the period is 98 .

Table 5: Descriptive Statistics

\begin{tabular}{llllll}
\hline Variable & $N$ & Mean & S.D & Min & Max \\
\hline$\left(C_{i t}\right)$ & 582 & 14885.24 & 8738.134 & 2239.636 & 34493.09 \\
$\left(Y_{i t}\right)$ & 594 & 28110.26 & 21544.09 & 1919.838 & 112000 \\
$\left(r_{i t}\right)$ & 565 & 1.077 & 3.869 & -12.507 & 25.21 \\
$\left(W_{i t}\right)$ & 427 & 98.554 & 20.662 & 38.125 & 209.43 \\
\hline
\end{tabular}

Source: Prepared by authors.

Table 4: Definition and Source of Variables

\begin{tabular}{|c|c|c|c|}
\hline Variables & Definition & Source & Unit \\
\hline Consumption Expenditure $\left(C_{i t}\right)$ & $\begin{array}{l}\text { Total Market Value of Goods and Services } \\
\text { Purchased by Households (Per Capita). }\end{array}$ & $\begin{array}{l}\text { World Development } \\
\text { Indicators (World Bank) }\end{array}$ & USD \\
\hline Income $\left(Y_{i t}\right)$ & Gross Domestic Product Per Capita & $\begin{array}{l}\text { World Development } \\
\text { Indicators (World Bank) }\end{array}$ & USD \\
\hline Real Interest Rate $\left(r_{i t}\right)$ & $\begin{array}{l}\text { Quarterly average interest rate (adjusted } \\
\text { using gross domestic product deflator) }\end{array}$ & $\begin{array}{l}\text { AMECO (EU Annual } \\
\text { Macroeconomic } \\
\text { Database) }\end{array}$ & $\begin{array}{l}\text { Percentage } \\
(\%)\end{array}$ \\
\hline Wealth $\left(W_{i t}\right)$ & Housing Price Index (Instrument Variable) & $\begin{array}{l}\text { BIS (Bank for } \\
\text { International } \\
\text { Settlement) }\end{array}$ & $2010=100$ \\
\hline
\end{tabular}

Note: The data set of the study covers 200-2017 period. EU-28 and negotiating countries included'.

\footnotetext{
${ }^{1}$ Malta excluded from the analysis due to lack of data. Negotiating Countries: Bosnia and Herzegovina, Kosovo, Macedonia, Serbia, Turkey. (Montenegro and Albania are not included in the analysis due to lack of data)
} 


\subsection{Methodology}

The estimation process of the income-consumption relationship requires the use of a more general approa$c h$ than the linear model for two main reasons. The first of these related to the distribution of the dependent variable. If the dependent variable has a distribution characteristic other than the normal distribution, the estimators may lose their unbiasedness properties. The second reason is that the economic relationship is mostly nonlinear.

The generalized linear model is represented as follows:

$$
g\left(\mu_{i}\right)=g\left[E\left(y_{i}\right)\right]=x_{i} \beta
$$

Where $x_{i}$ refers to the explanatory variables and $\beta$ refers to the regression coefficients. The components of the generalized linear model are expressed as follows (Nelder \& Wedderburn, 1972):

1) Distribution of dependent variable: probability density function $(f(y: \theta, \phi))$ is in the exponential family with $\theta, \phi$ parameters.
2) Systematic component $\eta: \eta=X \beta$,

3) Link function: $g: E(y)=\mu=g^{-1}(\eta)$

The link function relates the expected value of $\mu$ with the linear component $\eta$. In other words, the link function defines the relationship between independent and dependent variables. This may be any differentiable monotonic function. The literature provides a piece of preliminary information on the distribution under which the modeling process is conducted. Gamma distribution is regarded as one of the statistical distributions that have descriptive power on the income distribution (McDonald, (1984); Salem \& Mount, (2006); McDonald \& Jensen, (1979); Kloek \& van Dijk, (1978), Bandourian, McDonald \& Turley, (2002)). The main advantage of utilizing the gamma distribution is that it is defined only as positive values ((Thom, 1958); (Wilks, 1968)).

The probability density function of the gamma distribution is presented as follows (Minka, 2002):

$$
\begin{aligned}
& p(x \mid a, b)=G a(x ; a, b)=\frac{x^{a-1}}{\Gamma(a) b^{a}} \exp \left(-\frac{x}{b}\right) \\
& \begin{aligned}
\log p(D \mid a, b)=(a-1) & \sum_{i=1}^{n} \log x_{i}-n \log \Gamma(a)-n a \log b-\frac{1}{b} \sum_{i} x_{i} \\
& =n(a-1) \overline{\log x}-n \log \Gamma(a)-n a \log b-n \bar{x} / b
\end{aligned}
\end{aligned}
$$

In this context, MLE estimators are the parameters that maximize the logarithmic likelihood function. This process (MLE) requires a full description of the model and determination of the probability distribution. The GMM model eliminates this disadvantage of MLE (Matyas, 1999). In economics, GMM is mainly used in dynamic panel data models ((Baltagi \& Levin, (1986); (Holtz-Eakin, Newey, \& Rosen, (1988); Arellano \& Bond (1991); (Blundell, Bond, Devereux, \& Schiantarelli, (1992); (Islam, (1995); (Ziliak, (1997); (Baltagi, (2005); (Balestra \& Nerlove, (2006)). The dynamic panel data model is expressed as follows:

$$
y_{i t}=\delta y_{i, t-1}+x_{i t}^{\prime} \beta+u_{i t}
$$

Since the lag of the dependent variable is included among the independent variables, the assumption of strict externality is relaxed. Therefore, when $T$ is constant and $N$ goes to infinity, the dynamic model is applied because ordinary panel data models (fixed and random effects) cannot provide efficient estimators (Cameron \& Trivedi, 2005). Additionally, the two main problems arising from the dynamic model are autocorrelation and heterogeneity in unit effects. The GMM process proposed by Arellano and Bond (1991) provides solutions to autocorrelation and heterogeneity problems.

In this study, the reliability of traditional GLM parameters are tested using GLM based on machine learning. Machine learning is a sub-branch of artificial intelligence consisting of modelling that makes inferences from existing data using mathematical and statistical methods and makes forecasts by these inferences (Akay, 2018). In traditional GLM, the objective function is presented as follows (Nykodym, Kraljevic, Wang, \& Wong, 2019):

$$
\underset{\beta}{\max }[\text { GLM } \log \text { Likelihood }]
$$


The data set used in the estimation process is divided into two parts as training and test data by machine learning iteration. Therefore, when the model learns the signal (mathematical form) and noise (error term), the algorithm that works with the training data yields estimators that include the error term. This problem is referred to as "overfitting". To avoid this, the coefficients are reduced by adding a regularization penalty to the objective function:

$\max _{\beta, \beta_{1}}[$ GLM log Likelihood -regularization penalty ]

The coefficient estimates are obtained by analyzing the following optimization process:

$$
\max _{\beta, \beta_{1}} \sum_{i=1}^{N} \log f\left(y_{i} ; \beta, \beta_{1}\right)-\lambda\left(\alpha\|\beta\|_{1}+\frac{1}{2}(1-\alpha)\|\beta\|_{2}^{2}\right)
$$

Regularization penalties is applied to reduce the variance of the prediction error. The two penalized regressions are Ridge and Lasso (Least Absolute Shrinkage and Selection Operator). The parameter represents the choice between these two approaches. In the equation, Ridge regression occurs if $a=1$ and LASSO if $a=0$. The degree of regularization is determined by parameter $\lambda$. For example, if $\lambda=0$, no regularization is applied.

The models are established to estimate the most appropriate consumption function of the European Union and negotiating countries are listed as follows:

Model I: $\ln C_{i t}=\mu+\beta \ln Y_{i t}$

Model II: $\ln C_{i t}=\mu+\beta_{1} Y_{i t}+\beta_{2} \ln W_{i t}$

Model III: $C_{i t}=\mu+\beta_{1} C_{i(t-1)}+\beta_{2} Y_{i t}+\beta_{3} R_{i t}$

Model IV: $C_{i t}=\mu+\beta_{1} C_{i(t-1)}+\beta_{2} C_{i(t-2)}+\beta_{3} C_{i(t-3)}+\beta_{4} C_{i(t-4)}$

Where $C_{i t}$ refers to per capita consumption, $Y_{i t}$ per capita income, $w_{i t}$ refers to wealth, and $R_{i t}$ refers to the real interest rate. Following the evaluation of both models, the interest rate and the lagged value of consumption are added to the model in the context of the permanent income hypothesis on "adaptive expectations" assumption. The mathematical transformations executed in this framework are presented as follows:

$$
C=C^{P}+C^{T} \quad \text { and } \quad C_{t}^{P}=\alpha+\beta Y_{t}^{P}
$$

Where $C^{P}$ and $Y_{t}^{P}$ represents the permanent consumption and the permanent income respectively. Since these are not directly observable, the following adjustment is made ((Gujarati, 2004); (Manitsaris, 2006)):

$$
\begin{aligned}
& C_{t}-C_{t-1}=\theta\left(C_{t}^{P}-C_{t-1}\right)+\varepsilon_{t},(0<\theta \leq 1) \\
& Y_{t}^{P}-Y_{t-1}^{P}=\varphi\left(Y_{t}-Y_{t-1}^{P}\right)+\varepsilon_{t},(0<\varphi \leq 1)
\end{aligned}
$$

Where $\theta$ is the partial adaptation coefficient and $\varphi$ is the adaptive expectation coefficient:

$$
C_{t}=\alpha+\beta Y_{t}^{P}+C_{t}^{T},
$$

or,

$$
C_{t}=\alpha+\beta Y_{t}^{P}+v_{t},\left(v_{t}=\varepsilon_{t}+C_{t}\right)
$$

Equation (11) is restated as follows:

$$
\begin{aligned}
& Y_{t}^{P}=\frac{1}{\beta} C_{t}-\frac{\alpha}{\beta}-\frac{1}{\beta} v \\
& Y_{t-1}^{P}=\frac{1}{\beta} C_{t-1}-\frac{\alpha}{\beta}-\frac{1}{\beta} v_{t-1}
\end{aligned}
$$

Following Koutsoyiannis, (1979) and Alimi, (2015), we combine equations to convert them into a predictable format using observable values and to estimate long run $\mathrm{mpc}$;

$$
\begin{aligned}
& C_{t}=\alpha \omega+\beta \omega Y_{t}+(1-\omega) C_{t-1}+\left[v_{t}-(1-\omega) v_{t-1}\right] \\
& m p c_{L R}=\frac{\Omega_{1}}{1-\Omega_{2}}
\end{aligned}
$$

\section{ANALYSIS}

Concerning the objective of this study, it is expected that the estimators obtained under the normal distribution assumption will be biased if the distribution of economic data is non-normal. Table 6 presents coefficient estimates for traditional consumption functions under the gamma distribution.

According to the findings in Model 1, the reliability of the estimators of the Keynesian consumption function is not fit well in terms of theoretical expectations and statistical significance. The link test indicates that the model is not consistent in terms of statistical 
distribution and functional form. The estimators of the Model 2 are economically valid (Mpc $=0.88$ out of disposable income and 0.07 out of wealth). However, in the context of the link test, the model is rejected because the combination of statistical distribution and link function is not appropriate. Therefore, this model is not reliable in the context of long-term forecasting.

Among all four-model specifications, the most useful estimators for forecasting are obtained from the permanent income hypothesis (Model III). The consumption function estimated by Hall (1978), tested in the structure of Model IV. Although estimators of this model are significant, it does not eliminate the uncertainties about the coefficient of the lag of consumption in Model 3. In this context, Model 4 is significant but does not provide supportive evidence for the policy structure in terms of consumption expenditure. In summary, considering that the GLM approach, the main outcome of the four models is that the permanent income hypothesis appears robust.

All estimators in Model 3 are statistically significant. The short run $\mathrm{mpc}$ is 0.31 . The adaptive expectation coefficient is 0.37 (1-0.63). Interpreted together from these two estimators, the long-term $\mathrm{mpc}$ is calculated as follows:

$$
\frac{\Omega_{1}}{1-\Omega_{2}}=\frac{0.31}{(1-0.63)}=\frac{0.31}{0.37}=0.83
$$

To test the above controversial findings with stronger evidence, permanent income and random walk hypotheses are estimated using the GMM model. Absolute and life cycle income models are excluded from this process because of their static structures. The findings presented in Table 7 are quite consistent with the GLM model estimators.

Here, as in the GLM technique, although the distribution property of the independent variables is not taken into consideration, sample moments are applied to population moments. Based on the AR1 and AR2 statistics, there is no autocorrelation problem. In addition, the validity of the instrumental variables is tested by Sargan test. Accordingly, instrument variables are robust.

Table 6: Comparative Consumption Functions: GLM Findings

\begin{tabular}{|c|c|c|c|c|}
\hline & (Model 1) & (Model 2) & (Model 3) & (Model 4) \\
\hline$Y_{i t}$ & $\begin{array}{l}1.000^{* * * *} \\
(43.86)\end{array}$ & $\begin{array}{l}0.881^{* * *} \\
(21.28)\end{array}$ & $\begin{array}{l}0.311^{* * *} \\
(7.14)\end{array}$ & \\
\hline$W_{i t}$ & & $\begin{array}{l}0.0769^{* * * *} \\
(4.45)\end{array}$ & & \\
\hline$C_{t-1}$ & & & $\begin{array}{l}0.632^{* * *} \\
(15.79)\end{array}$ & $\begin{array}{l}1.321^{* * *} \\
(18.02)\end{array}$ \\
\hline$C_{t-2}$ & & & & $\begin{array}{l}-0.619^{* * * *} \\
(-5.01)\end{array}$ \\
\hline$C_{t-3}$ & & & & $\begin{array}{l}0.131 \\
(1.57)\end{array}$ \\
\hline$C_{t-4}$ & & & & $\begin{array}{l}0.0172 \\
(0.40)\end{array}$ \\
\hline$R_{i t}$ & & & $\begin{array}{l}-0.00363^{* * * *} \\
(-4.90)\end{array}$ & \\
\hline$\mu$ & $\begin{array}{l}-0.641^{* *} \\
(-2.62)\end{array}$ & $\begin{array}{l}0.290 \\
(0.75)\end{array}$ & $\begin{array}{l}0.384^{* *} \\
(2.68)\end{array}$ & $\begin{array}{l}1.515^{* * * *} \\
(8.01)\end{array}$ \\
\hline Linktest $\left(\hat{y}^{*}\right)$ & 0.00 & 0.00 & $0.26^{* * *}$ & $0.96^{* * *}$ \\
\hline$A C$ & 6.58 & 6.65 & 6.61 & 6.64 \\
\hline
\end{tabular}

$t$ statistics in parentheses

${ }^{*} p<0.05,{ }^{* * *} p<0.01,{ }^{* * *} p<0.001$ 
Table 7: Permanent Income and Random Walk Hypothesis: System GMM Results

\begin{tabular}{|c|c|c|}
\hline & (Model 3) & (Model 4) \\
\hline \multirow[t]{2}{*}{$\overline{Y_{i t}}$} & $0.320^{* * *}$ & \\
\hline & $(8.03)$ & \\
\hline \multirow{2}{*}{$C_{(t-1)}$} & $0.592^{* * *}$ & $1.614^{* * *}$ \\
\hline & $(13.25)$ & $(14.49)$ \\
\hline \multirow[t]{2}{*}{$C_{(t-2)}$} & & $-0.793^{* * *}$ \\
\hline & & $(-3.60)$ \\
\hline \multirow[t]{2}{*}{$C_{(t-3)}$} & & 0.211 \\
\hline & & $(1.04)$ \\
\hline \multirow[t]{2}{*}{$C_{(t-4)}$} & & -0.0391 \\
\hline & & $(-0.42)$ \\
\hline \multirow[t]{2}{*}{$R_{i t}$} & $-0.003^{* * *}$ & \\
\hline & $(-3.40)$ & \\
\hline \multirow[t]{2}{*}{$\mu$} & $0.65^{* * *}$ & . \\
\hline & $(5.46)$ & \\
\hline$S$ & - & 266.3 \\
\hline $\mathrm{m} 1$ & $-2.07^{*}$ & -2.643 \\
\hline $\mathrm{m} 2$ & $-1.75^{* * *}$ & $-0.00144^{* * *}$ \\
\hline
\end{tabular}

$t$ statistics in parentheses. ${ }^{*} p<0.05,{ }^{* *} p<0.01,{ }^{* * *} p<0.001$

According to the estimators in Table 7, the $\mathrm{mpc}=0,32$ in the short run in the long run it is 0,78 . In addition to these findings, the table presents the findings of the random walk hypothesis. These are very similar to those obtained from the GLM model. The model is statistically significant. At the same time, according to ar1 and ar2 statistics, the autocorrelation hypothesis is rejected. In addition, instrumental variables are statistically significant.

GLM and GMM estimators provide strong evidence of the validity of the permanent income hypothesis. Besides, the estimators obtained by the two methods are compatible. Economically, the coefficients obtained from both models reveal that many consumers behave under the permanent income hypothesis, that is if the increases in income are permanent, the expenditures and thus the total demand will increase. Short-run income shocks will have a relatively limited effect.

The estimator of the lagged consumption expenditures $C_{i(t-1)}$ is greater than expected, thus it maintains the potential for doubt in terms of long-term forecasting. Therefore, the estimators were tested using machine learning methods. The results are presented in the table below, Table 8 .
The significance of the models was measured using several statistical indicators ${ }^{2}$. According to the statistical indicators obtained in both models, LASSO regression provides better estimators. The model indicates that short and long run marginal propensity to consume are 0.51 and $0.78(0.513 /(1-0.34))$ respectively.

Table 8: Permanent Income Hypothesis: GLM Results Based on Machine Learning

\begin{tabular}{lll}
\hline & LASSO & RIDGE \\
\hline$C_{i(t-1)}$ & Logc & Logc \\
$Y_{i t}$ & $0.344^{*}$ & $0.292^{*}$ \\
$\mathrm{R}$ & $0.513^{*}$ & $0.523^{*}$ \\
cons & $-0.002^{*}$ & $-0.00^{*}$ \\
\hline MSE & $1.04^{*}$ & $1.43^{*}$ \\
\hline
\end{tabular}

Source: Obtained under the $\mathrm{R}$ software using the $\mathrm{H} 2 \mathrm{O}$ package.

The estimators are tested by using cross-validation. In this process, separate model estimators were obtained by selecting different data for the test and training

${ }^{2}$ These are; mean square error $\left(M S E=\frac{1}{N} \sum_{i=1}^{N}\left(y-\widehat{y)^{2}}\right)\right.$, mean absolute error $\left(M A E=\frac{1}{N} \sum_{i=1}^{N} \mid \varepsilon_{i}\right)$ and root mean square error $\left(R M S E=\sqrt{\frac{\sum_{i=1}^{N}(y-\widehat{y})^{2}}{N}}\right.$. 
parts at each stage. Then, the statistical indicators (RMSE, MSE, MAE, etc.) obtained at each stage were compared. Accordingly, changes in statistical indicators show whether the model parameters are consistent. At this stage, the findings of the four randomly selected subsets of cross validation are as follows:

Table 9: Cross-Validation Results

\begin{tabular}{lll}
\hline Indicators & Mean & Std.D. \\
\hline MSE & 0.01 & 0.005 \\
RMSE & 0.1 & 0.009 \\
MAE & 0.067 & 0.005 \\
\hline
\end{tabular}

Source: Obtained under the R software using the $\mathrm{H} 2 \mathrm{O}$ package.

In summary, the estimators of all three approaches used in the modelling stage (GLM, GMM and Machine Learning) are comparable. In the long run, the marginal propensity to consume $(\mathrm{mpc})$ is estimated to be 0.83 in the traditional GLM approach, 0.86 in the GMM approach and 0.78 in the Machine Learning approach. In addition, the estimators of the real interest rate are very close to each other. This indicates that the estimators are reliable. At the same time, there is strong evidence for the validity of the permanent income hypothesis in the sample of the member states of the European Union and the countries in the negotiation process.

\section{CONCLUSION}

In this paper, coefficient estimates of traditional consumption functions were analyzed individually.
Consequently, it is revealed that estimators obtained from the Keynesian consumption function are not strong. Besides, estimators of the life cycle hypothesis, though economically significant, are not statistically efficient. GLM estimators of the permanent income hypothesis are significant. However, the estimator of the one-period lag of consumption casts doubt on the ability to make forecasts and present policy proposals. In this context, within the framework of comparative model findings, the main conclusion we draw from all four models is that estimates of the permanent income hypotheses are the most efficient.

To test the reliability of GLM findings, permanent income, and random walk hypotheses were estimated by the GMM method. The fact that the GLM and GMM estimates are highly compatible with each other presents strong evidence of the validity of the permanent income hypothesis. For the machine learning-based GLM technique, the marginal propensity of consumption was estimated at 0.51 and 0.78 in the short and long-run respectively. The coefficients from all three approaches reveal that many consumers behave under the permanent income hypothesis. Accordingly, consumption expenditures will increase if the increase in income is perceived as permanent. As a result, the composition of developed countries in the European Union sample, in general, makes the results of the study more reliable. In future studies, it will be useful to study consumption behaviors within the theoretical framework using microdata in developed and developing countries in terms of monetary and fiscal policy applications. 


\section{References}

Alegre, J., \& Pou, L. (2008). Further evidence of excess sensitivity of consumption? Nonseparability among goods and heterogeneity across households. Applied Economics, 40(7), 931-948. https://doi. org/10.1080/00036840600749896

Alimi, R. S. (2013). Keynes' absolute income hypothesis and Kuznets paradox. Munich Personal RePEc Archive, (49310), 1-15. Retrieved from https://mpra. ub.uni-muenchen.de/49310/

Alimi, S.R. (2015), Estimating Consumption Function under Permanent Income Hypothesis: A Comparison between Nigeria and South Africa. International Journal of Academic Research in Business and Social Sciences, 5(11), 285-298.

Altunç, Ö. F., \& Aydın, C. (2014). An Estimation of the Consumption Function Under the Permanent Income Hypothesis: The Case of D-8 Countries. Journal of Economic Cooperation and Development, 35(3), 29-41.

Anderson, T. W., \& Hsiao, C. (1981). Estimation of dynamic models with error components. Journal of the American statistical Association, 76(375), 598-606.

Arellano, M., \& Bond, S. (1991). Some Tests of Specification for Panel Carlo Application to Data: Review of Economic Studies, 58, 277-297.

Arellano, M., \& Bover, O. (1995). Another look at the instrumental variable estimation of error-components models. Journal of Econometrics, 68(1), 29-51.

Balestra, P., \& Nerlove, M. (2006). Pooling Cross Section and Time Series Data in the Estimation of a Dynamic Model: The Demand for Natural Gas. Econometrica. https://doi.org/10.2307/1909771

Baltagi, B. (2008). Econometric analysis of panel data. John Wiley \& Sons.

Baltagi, Badi H., \& Levin, D. (1986). Estimating Dynamic Demand for Cigarettes Using Panel Data:The Effects of Bootlegging, Taxation and Advertising Reconsidered. The Review of Economics and Statistics. https:// doi.org/10.2307/1924938

Bilgili, F. (2006). Random walk, excess smoothness or excess sensitivity? Evidence from literature and an application for Turkish economy. In: International Conference on Economics. Consumption in Turkey, Ankara, Turkey, September 12, 2006.

Bilgili, F., \& Bağlıtaş, H. H. (2016). Testing the permanent income and random walk hypotheses for Turkey. International Journal of Economics and Financial Issues, 6(4), 1371-1378.
Blundell, R., \& Bond, S. (1998). Initial conditions and moment restrictions in dynamic panel data models. Journal of Econometrics, 87(1), 115-143. https://doi. org/10.1016/S0304-4076(98)00009-8

Blundell, R., Bond, S., Devereux, M., \& Schiantarelli, F. (1992). Investment and Tobin's Q: Evidence from company panel data. Journal of econometrics, 51(12), 233-257.

Bandourian, R., McDonald, J., \& Turley, R. S. (2002). A comparison of parametric models of income distribution across countries and over time.

Bunting, D. (1989). The consumption function "paradox". Journal of Post Keynesian Economics, 11(3), 347-359.

Cameron, C. A., \&Trivedi, P. A. (2005). Microeconometrics Methods and Applications. New York: Cambridge University Press.

Campbell, J. Y., \& Mankiw, G. N. (1990). Permanent Income, Current Income, and Consumption. Journal of Business \& Economic Statistics, 8(3), 265-280.

Campbell, J. Y., \& Mankiw, N. G. (1991). The response of consumption to income: a cross-country investigation. European economic review, 35(4), 723-756.

Carroll, D. C., Slacalek, J., \& Tokuoka, K. (2014). The Distribution of Wealth and the MPC : Implications of New European Data. The American Economic Review, 104(5), 107-111.

Carruth, A., Gibson, H., \& Tsakalotos, E. (2010). Are aggregate consumption relationships similar across the European Union? Regional Studies, 33(1), 17-26. https://doi.org/10.1080/00343409950118887

Coskun, Y., Sencer Atasoy, B., Morri, G., \& Alp, E. (2018). Wealth effects on household final consumption: Stock and housing market channels. International Journal of Financial Studies, 6(2), 57.

Davis, J. A. (1959). A formal interpretation of the theory of relative deprivation. Sociometry, 22(4), 280-296.

Deaton, A. (1987). Estimation of own-and cross-price elasticities from household survey data. Journal of Econometrics, 36(1-2), 7-30.

Deaton, A. (2005). Franco Modigliani and the Life Cycle Theory of Consumption. Research Program in Development Studies and Center for Health and Wellbeing. Princeton University.

DeJuan, J. P., Seater, J. J., \& Wirjanto, T. S. (2006). Testing the permanent-income hypothesis: New evidence 
from West-German states (Länder). Empirical Economics, 31(3), 613-629.

Dornbusch, R., Fischer, S., \& Bossons, J. D. (Eds.). (1987). Macroeconomics and finance: essays in honor of Franco Modigliani. Mit Press.

Emilio Fernandez-Corugedo. (2004). Consumption Theory. In Handbooks in Central Banking.

Flavin, M. A. (1981). The Adjustment of Consumption to Changing Expectations About Future Income. Journal of Political Economy, 89(5), 974-1009. https://doi. org/10.1086/261016.

Ferber, R. (1966). Research on household behaviour. In Surveys of Economic Theory (pp. 114-154). Palgrave Macmillan, London.

Gujarati, D. N. (2004). Basic Econometrics. Fourth Edition. McGraw-Hill, New York. USA. In Science. https:// doi.org/10.1126/science.1186874

Hall, R. E., \& Mishkin, F. S. (1982). The Sensitivity of Consumption to Transitory Income: Estimates from Panel Data on Households. Econometrica, 50(2), 461. https://doi.org/10.2307/1912638

Hayashi, F. (1982). The Permanent Income Hypothesis : Estimation and Testing by Instrumental Variables. Journal of Political Economy, 90(5), 895-916.

Holtz-Eakin, D., Newey, W., \& Rosen, H. S. (1988). Estimating vector autoregressions with panel data. Econometrica: Journal of the Econometric Society, 1371-1395.

Hurd, M. D., \& Rohwedder, S. (2005). Changes in consumption and activities in retirement. Michigan Retirement Research Center Research Paper No. WP, 96.

lanole, R., \& Druıcă, E. (2015). Testing the Keynesian consumption hypothesis on European panel data. Revista Romana de Economie, 40(1).

Islam, N. (1995). Growth empirics: a panel data approach. The quarterly journal of economics, 110(4), 1127-1170.

Jawadi, F., \& Sousa, R. M. (2015). The Relationship between Consumption and Wealth: A Quantile Regression Approach. Revue d'économie Politique, 124(4), 639. https://doi.org/10.3917/redp.244.0639.

Kankaanranta, P. (2006). Consumption Over the Life Cycle: Theory and Empirical Regularities (No. 118).

Kaldor, N. (1955). Alternative Theories of Distribution. The Review of Economic Studies, 23(2), 83. https:// doi.org/10.2307/2296292

Keynes, J. M. (1936a). The general theory of employment, interest, and money. In The General Theory of Employment, Interest, and Money. https://doi. org/10.1007/978-3-319-70344-2

Kloek, T., \& van Dijk, H. K. (1978). Efficient estimation of income distribution parameters. Journal of Econometrics, 8(1), 61-74. https://doi.org/10.1016/03044076(78)90090-8

Koutsoyiannis, A. (1979). Modern microeconomics. (Second). New York: Macmillan.

Kuznets, S. (1946). National product since 1869. National Bureau of Economic Research, New York.

Manitsaris, A., 2006 "Estimating the European Union Consumption Function under the Permanent Income Hypothesis."International Research Journal of Finance and Economics, 2(3):1450-288

Mátyás, L., Gourieroux, C., \& Phillips, P. C. (Eds.). (1999). Generalized method of moments estimation (Vol. 5). Cambridge University Press.

McDonald, J. B. (1984). Some Generalized Functions for the Size Distribution of Income. The Econometric Society Stable, 52(3), 647-663.

McDonald, J. B., \& Jensen, B. C. (1979). An analysis of some properties of alternative measures of income inequality based on the gamma distribution function. Journal of the American Statistical Association, 74(368), 856-860.

Minka, T. P. (2002). Estimating a Gamma Distribution. Microsoft Research, 1(3), 3-5.

Modigliani, F., \& Ando, A. (1963). The "Life Cycle" Hypothesis of Saving: Aggregate Implications and Tests. The American Economic Review, 53(1), 55-84.

Modigliani, F., \& Brumberg, R. (1954). Utility analysis and the consumption function: An interpretation of cross-section data. Franco Modigliani, 1(1), 388-436.

Nelder, J. A., \& Wedderburn, R. W. (1972). Generalized linear models. Journal of the Royal Statistical Society: Series A (General), 135(3), 370-384.

Nykodym, T., Kraljevic, T., Wang, A., \& Wong, W. (2019). Generalized Linear Modeling with H2O (Sixth Edit; A. Bartz, ed.). Retrieved from http://docs.h2o.ai/h2o/ latest-stable/h2o-docs/booklets/GLMBooklet.pdf.

Okcu, A. B. (2008). Türkiye İçin Gelir-Tüketim İlişkisinin Eşbütünleşme Analizi İle İncelenmesi. Çukurova Üniversitesi.

Poterba, J. M. (1988). Are consumers forward looking? Evidence from fiscal experiments. The American Economic Review, 78(2), 413-418.

Pressman, S. (1997). Consumption, income distribution and taxation: Keynes' fiscal policy. Journal of Income 
Distribution, 7(1), 29-44. https://doi.org/10.1016/ s0926-6437(97)80003-0

Rao, B. B. (2005). Testing Hall's permanent income hypothesis for a developing country: the case of Fiji. Applied Economics Letters, 12(4), 245-248.

Salem, A. B., \& Mount, T. D. (1974). A convenient descriptive model of income distribution: the gamma density. Econometrica: journal of the Econometric Society, 1115-1127.

Sargan, J. D. (1958). The estimation of economic relationships using instrumental variables. Econometrica: Journal of the Econometric Society, 393-415.

Sivri, U., \& Eryüzlü, H. (2010). Rasyonel Beklentiler-Yaşam Boyu Sürekli Gelir Hipotezinin Testi. Ekonometri ve Istatistik E-Dergisi, 1(11), 90-99.

Slacalek, J. (2004). International Evidence on Cointegration between Consumption, Income, and Wealth. Unpublished manuscript. Available at http:// www. slacalek. com/research. $h$ tml.
Slacalek, J. (2009). What drives personal consumption? the role of housing and financial wealth. B.E. Journal of Macroeconomics, 9(1). https://doi. org/10.2202/1935-1690.1555.

Smith, S. (2004). Can the retirement consumption puzzle be resolved? Evidence from UK panel data (No. 04/07). IFS Working Papers.

Souleles, N. S. (2002). Consumer response to the Reagan tax cuts. Journal of Public Economics, 85(1), 99-120. https://doi.org/10.1016/S0047-2727(01)00113-X

Thom, H. C. S. (1958). A note on the gamma distribution. Monthly Weather Review, 86(3), 117-122. https:// doi.org/10.1175/1520-0493(1958)086<0117:a notgd $>2.0 . \mathrm{co} ; 2$

Wilks, D. S. (1968). Statistical methods in the atmospheric sciences: an introduction. In International Geophysics Series.

Ziliak, J. P. (1997). Efficient estimation with panel data when instruments are predetermined: an empirical comparison of moment-condition estimators. Journal of Business \& Economic Statistics, 15(4), 419-431. 